\title{
Educational Reform of Car Marketing Teaching Based on Project-driven Method
}

\author{
Xuan Chen \\ Qingdao Binhai University \\ Shandong, China \\ chenxuanjt@163.com
}

\author{
Huimin Zheng \\ Qingdao Binhai University \\ Shandong, China \\ zhmhappy@126.com
}

\begin{abstract}
Currently, the depressed practical ability of vocational graduates can't meet the vocational need. Directing at the present situation, it proposes a project-driven method to promote students' vocational ability. With flexible teaching methods, the educational reform mainly bases on the practical projects to stimulate students' participation, enhance their practical ability and further encourage the seamless connection between the vocational education and the demands of employment.
\end{abstract}

Keywords-Project-driven method, Car marketing teaching, Educational reform

\section{BACKGROUND}

Higher vocational education at this stage are vigorously promote the combination of engineering education model, most of the school's usual practice is to set up experiments subjects or practical aspects, to use theoretical knowledge into practice[1]. Practice teaching is to cultivate students' practical ability as the goal, to simulate real working environment in practice, and get full workout. But the practical teaching requires high quality of laboratory, practice base, a variety of instruments and facilities to ensure. Because of the active participation of companies is not high, the effect of part of the course is not good[2].

Automotive marketing course is a practical and applicationoriented course, which provides the basic marketing knowledge and marketing skills. However, the traditional teaching method has the following disadvantages: firstly, theoretical knowledge of teaching content is too much and practice portion is less than normal; secondly, teaching methods is outdated, which is mainly based on teachers' teaching; thirdly, in terms of means of teaching, there are too much theoretical knowledge, which hampers students' thinking space and their potential; at last, evaluation method basically follows the traditional evaluation methods, which is lack of flexible diversity.

\section{THINKING OF EDUCATIONAL REFORM}

\section{A. Focusing on vocational ability development}

The educational reform should closely rely on the advantages of industries and enterprises, and set up an operational mechanism which is closely integrated of producing, teaching and researching [3]. In order to fully reflect the occupational and practical teaching, deeply investigation on the expertise and ability is necessary. When the actual projects and tasks are released, students can develop their comprehensive professional ability during the process of solving problems.

\section{B. Emphasizing the combination with practice}

The target of vocational education is to cultivate technical skills and talents[4]. To promote employment, theory teaching needs to combine with practice teaching, and focus on training comprehensive ability, such as the students' ability on practical, innovation and entrepreneurship.

\section{Promoting students learning initiative}

Through the thought of student-centered, boring and unpractical theoretical teaching should be reduced. According to the actual demand, teachers are encouraged to use a variety of classes to promote students' full participation[5].

\section{REFORM PROGRAM}

“Automotive Marketing” is a very practical course, which is important for broadening students' knowledge channels and increasing their field of view[6]. To avoid boring and monotonous content in the curriculum implementation process, a large number of simulation environment and virtual working platform is need to be established. Students' practical ability will be improved by learning the teaching methods, which combines with virtual and actual situation.

\section{A. Teaching content analysis}

Combined with characteristics of the course, the course content is divided into three parts: self-learning part, theoretical part and practical part. In theoretical part, the key knowledge is automotive market environment analysis, automotive market research and forecasting, purchase behavior analysis, automotive marketing 4Ps theory (products, price, place and promotion)[7]. The practice part mainly involves three tasks: customer development, customer reception and customer relationship. Content distribution is as follows: 
TABLE I.

AUTOMOTIVE MARKETING BASIC CONTENT ANALYSIS

\begin{tabular}{|c|c|c|c|}
\hline Module & Task of teaching & Main points & Lesson hour \\
\hline \multirow{3}{*}{$\begin{array}{l}\text { theoretical } \\
\text { module }\end{array}$} & $\begin{array}{l}\text { Project 1: Automotive marketing } \\
\text { environment analysis }\end{array}$ & $\begin{array}{l}\text { Macro environment, micro-environment } \\
\text { and market opportunities }\end{array}$ & 10 \\
\hline & $\begin{array}{l}\text { Project 2: Automotive market research and } \\
\text { forecasting }\end{array}$ & $\begin{array}{l}\text { Automotive market research and market } \\
\text { forecasts }\end{array}$ & 10 \\
\hline & $\begin{array}{l}\text { Project 3: Automotive product marketing } \\
\text { Strategies }\end{array}$ & $\begin{array}{l}\text { 4Ps theory (products, price, place and } \\
\text { promotion) }\end{array}$ & 18 \\
\hline \multirow{3}{*}{$\begin{array}{l}\text { Practice } \\
\text { module }\end{array}$} & Project 4: Customer development & Individual customers and market customers & 8 \\
\hline & Project 5: Customer reception & Reception, offer and deal & 10 \\
\hline & Project 6:Customer relationship & $\begin{array}{l}\text { Keep in touch with customers, and wake } \\
\text { customers' enthusiasm }\end{array}$ & 8 \\
\hline
\end{tabular}

\section{B. Teaching steps design}

In order to improve the ability of combining theory with practice, teaching steps are designed in accordance with projects and tasks[8]. Teaching steps include assigning tasks, knowledge learning, data collection, and completing tasks.

\section{a) Assigning tasks}

Tasks are the problem to be solved in the actual work, and they should be assigned based on the actual working environment. Students build their own team. Taking the automotive market research and forecasting project for example, teacher can issue the following tasks:

Gengchen car sales Services Ltd. intends to set up a 4S shop. The brands to be selected are Chevrolet, Audi, Peugeot, etc. The company needs to carry out a targeted research on car market in the region. Each team needs to conduct market research according to the requirements of a new $4 \mathrm{~S}$ shop. These teams will provide the basis for corporate decisions by questionnaire designing, investigative reports completing and future needs forecasting.

\section{b) Knowledge learning}

In this step, students are required to do independent learning to grasp the following knowledge: what are the content, procedures and methods of automotive market research; how to design a questionnaire; how to forecast the market demand; and how to write a market research report. Students in this step should be in conjunction with cases, so that they can better grasp the theoretical knowledge.

\section{c) Data collection}

To complete the practical task, all kinds of data are needed to collect. For example, when students do local automotive market research, they need to collect needs data of residents; students also need to investigate operating conditions of other $4 \mathrm{~s}$ shops and car sales in other regions, etc. Only the data is collected, organized and analyzed, the future demand can be forecasted.

In this step, students can get the needed data by the means of publishing online questionnaire, researching the actual $4 \mathrm{~s}$ shop, and doing random interviews of car buyers. They also should retain the original research data, such as the questionnaire on paper or network, audio and video files.

\section{d) Completing tasks}

In this step, everyone needs to organize a research report according to their research, and each team needs to report with PPT after summarizing their consequent.

Research report should address the following questions: why do we do this study; what's the method will be used in this study; which data needs to be surveyed; what's the result after your study; and through this research, whether there are suggestions and countermeasures or not ? The form of research report can be varied, in which, it with pictures and report forms described in Microsoft Word is the best.

Flow chart of the case is shown below. 


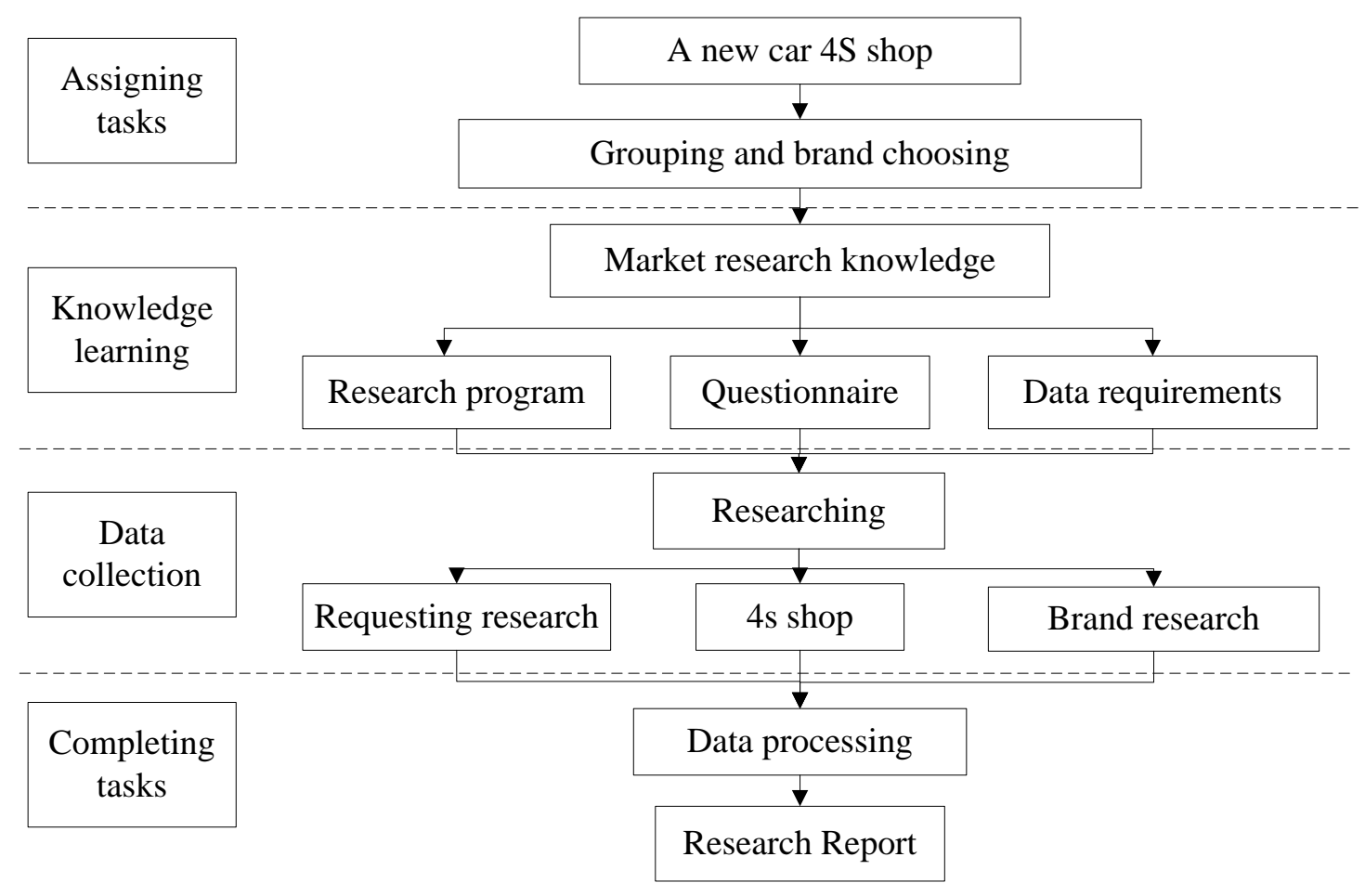

Fig. 1. Flow chart of the case

\section{Teaching methods reform}

Teaching method is the most important of all. Automotive marketing course is a very practical one, teachers need to combine with traditional teaching methods and modern educational technology[9]. According to the actual project, the reform modus of teaching methods are the following:

a) Turn "teaching" into "guiding"

In the traditional teaching methods, teacher is to teach, students only need to remember every point of knowledge teacher has taught. This can't exercise students' thinking ability and creativity. Only by taking the guiding method, students can be stimulated their creativity.

According to the characteristics of the course, theoretical knowledge can be self-learning by the students, and deepen in practice. In class, teacher changes the traditional teaching method into new guiding method, which can guide students to think and find new solutions.

\section{b) Turn "lecturing" into "discussing"}

To avoid boring theoretical knowledge, teacher will carefully set related cases, to enhance students' understanding of the theory during case analysis and discussion. The classroom is changed into the moot site; students in the debate can not only master the theoretical knowledge, but also exercise the ability to solve practical problems.

c) Turn "attending" into "communicating"

With the learning of theoretical knowledge, teacher constantly assigns practice tasks for students to analog actual marketing examples. Students search a lot of information, and complete the marketing plan before class, while they show their process in class. With the show on class, students can better explore their completion ideas. The classroom turns to the forefront of communication and marketing, and each student in class can play a role in it.

\section{Examination methods reform}

It is believed that if the examination method reform, good students will have more space to develop, and the periodic selftest will help students improving their self-learning ability[10]. The assessment method applied combines the procedural assessment with the final tests. All the tests utilize the form of flexible practice assessment, such as class debate, team work, surveys, actual sales simulation, PPT show and so on. After the reform of assessment methods, teacher can examine students' marketing capabilities, customer communication skills, teamwork skills and report writing capabilities.

\section{CONCLUSION}

Automotive marketing course is a combination of theory and practice. Students' ability to participate and dominate in class will be improved continuously, through teachers' design of teaching steps, reform of teaching methods and assessment methods. The effect is significant, after some college teachers actually run the reform measures. Driven by the actual project, Students' enthusiasm has been greatly improved. At the same time, students' sense of teamwork, innovation and ability to organize and analyze problems has made great progress. However, there are also some shortages to be improved. Such as in task setting, group assignment and practical exercise steps, it requires reasonable arrangement according to the actual situation. 


\section{REFERENCES}

[1] Wang Na, "Automotive Marketing" course reform exploration based on process, Communication of Vocational Education, vol.12, pp. 24-26, 2011. (In Chinese)

[2] Cai Zexiang, Liu Haiyan, Several angles of theory on practice teaching, China University Teaching, vol.3, pp. 79-80, 2007. (In Chinese).

[3] Zhu Hongmei, Vocational ability-oriented research on accounting practical teaching, Zhejiang Normal University, 2011. (In Chinese)

[4] Chai Xun. Application of case teaching method in law science teaching, Higher Education Research in Heilongjiang Province, vol.12, pp. 174176, 2015. (In Chinese).

[5] Peng Zhen, Li Yuanqing, Tourism professional curriculum reform in higher vocational based on competence training - take "Tourism Marketing" for example, Higher Agricultural Education, vol.9, pp. 116119, 2014. (In Chinese)
[6] Zhao Zhixia, Yin Hongwei, Tourism marketing of vocational curriculum reform project, New Curriculum Research, vol.1, pp. 37-39, 2012. (In Chinese).

[7] Tang Wen, Teaching reform of higher vocational college marketing course, Anhui Vocational and Technical College of Water Resources and Hydropower, 2005. (In Chinese).

[8] Cui Yuhua, Marketing teaching reform based on professional ability, Journal of Beijing Polytechnic College, vol.11, pp. 103-105, 2012. (In Chinese).

[9] Chen Yanyan, Study on fashion marketing curriculum reform experiential marketing mode, China Business \& Trade, vol.4, pp. 189190, 2014. (In Chinese).

[10] Guo Wei, Zhao Ping, Analysis on China marketing trend, New Wave, vol.4, pp. 56-57, 2004. (In Chinese). 